\title{
Oligodendroglioma の免疫組織学的，電顕的検討
}

\author{
神田享勉 \\ 群馬大学医学部第一病理学教室（主任：石田陽一教授）
}

\section{।はじめに}

1926年，Bailey and Cushing ${ }^{1)}$ は成人の大脳半球 に好発する独特な組織像を示す腫瘍型を記載し, oligodendroglia の腫瘍と考えて, oligodendroglioma と命名した。この腫瘍は細胞性で, 染色質に 豊む円形核を持つ細胞から成り核周の胞体は明るく 抜けて boxed-in appearance と呼ばれる特徵ある 組織像を示している。この腫瘍には星形グリア系細 胞の混在があり，しばしば mixed oligo-astrocytoma と呼ばれる混合構成を示す腫瘍が観察され る. Oligodendrogliomaの示す混合細胞構成につい ては, 最近抗 GFA 蛋白抗体を用いた免疫組織学的 検索によって確かめられている。この腫瘍型の超微 像は Luse $(1960)^{2)}$ によって始めて報告され, その後 もいくつかの報告がある. しかし，この腫瘍を構成 する細胞の超微像に関する記載はまちまちで, 超微 構造の特徵は必らずしも確立されているとは言い難 い. そこで, 神経特異蛋白である GFA 蛋白, S-100 蛋白の抗体を用い免疫組織学的に oligodendroglioma の細胞構成について検討を行なうと共に, 電 顕観察を行ない腫瘍構成細胞の超微像についても検 討した。

\section{II 検索材料と検索方法}

1. 検索材料

Oligodendroglioma の組織像を示す生検15例, 剖 検 2 例, 計17例の腫瘍組織。

2. (1) 組織学的検索

$10 \%$ buffered formalin 液中に固定された腫場組 織からパラフィン切片を作製し, H.E., P.T.A.H. 染 色を行なって光顕的に観察した。必要に応じてホル マリン固定腫揚組織から凍結切片を作製し, Cajalピリジン銀鍍銀法, 辻山炭酸銀鍍銀法を行なって検 索した。

（2）免疫組織学的検索
ホルマリン固定，パラフィン包埋切片で PAP 酵 素抗体法により, GFA 蛋白, S-100 蛋白の腫瘍組織 内局在を免疫組織学的に検索した. (Table 2.)

使用した抗 GFA 蛋白抗血清は, ganlioglioma の 組織像を示す七ト脳腫瘍組織から抽出精製した GFA 蛋白をウサギに免疫し, 抗 S-100 蛋白抗体は ウシ脳より抽出精製した S-100 蛋白をウサギに免疫 して作製した。GFA，S-100 蛋白の分離精製と抗血 清の作製については山口吕が報告している.

(3) 電顕的検索

手術時に摘出された 3 例の腫瘍組織の一部を Karnovsky 固定液に 4 時間浸積し,さらに $2 \%$ $\mathrm{OsO}_{4}$ で 2 時間後固定し Epon 又は Ouetol に包埋, LKB 超ミクロトームで超薄切片を作製しウラン鉛 二重染色を行なって JEM7A, 100C 電子顕微鏡で観 察した。

\section{III 観 察 結 果}

1. Oligodendroglioma の組織像

17例の腫瘍組織を組織学的に検索し, Table 1.の ように分類した。定型組織像を示す例は 6 例で，比 較的均一な形態を示す膠腫細胞の充実性増殖から 成っている(Fig. 1A). 細胞の胞体に相当する部分は 明るく抜けていて染色質に豊む円形の核は胞体の中 心に位置し，植物組織を思わせる独特な honeycombed structure を示している.毛細管構造を示す 血管も豊富で網目状の基質を形成している，基質に 石灰顆粒の沈着が認められる。症例により，或いは 同一腫湯でも観察部位によって核近傍に好酸性の狭 い胞体を認める腫瘍細胞もある．好酸性の広い胞体 を持つ星形グリア系細胞も腫瘍細胞の間に認めるこ とがある。辻山鍍銀法では核周囲の狭い胞体と繊細 な短突起に好銀性が認められた(Fig. 1E). Cajal-ピ リジン銀鍍銀法では核周囲の狭い胞体と繊細な短突 起に好銀性が認められた(Fig. 1F). Cajal-ピリジン 銀鍍銀法では，好銀性の太い突起を持つ細胞が混在 
Table 1. Cases of Oligodendroglioma Studied

\begin{tabular}{|c|c|c|c|c|c|c|}
\hline No. & Age & Sex & Location of Tumor & Histological Diagnosis & \multicolumn{2}{|c|}{ Remarks } \\
\hline 1 & 37 & M & lt. frontal lobe & Oligodenroglioma & $\mathrm{B}^{*}$ & $\mathrm{EM}^{* * *}$ \\
\hline 2 & 31 & $\mathrm{~F}$ & lt. frontal lobe & Oligodendroglioma & $\mathrm{B}$ & EM \\
\hline 3 & 54 & $\mathrm{~F}$ & lt. fronto-temporal lobe & Anaplastic oligodendroglioma & $\mathrm{B}$ & \\
\hline 4 & 31 & M & rt. frontal lobe & Anaplastic oligodendroglioma & $\mathrm{B}$ & \\
\hline 5 & 46 & M & lt. frontal lobe & Anaplastic oligodendroglioma & $\mathrm{B}$ & \\
\hline 6 & 52 & $\mathrm{~F}$ & blt. frontal lobe & Mixed oligoastrocytoma & $\mathrm{B}$ & $\mathrm{EM}$ \\
\hline 7 & 43 & $\mathrm{~F}$ & lt. temporal lobe & Oligodendroglioma & $\mathrm{B}$ & \\
\hline 8 & 35 & $\mathrm{~F}$ & rt. frontal lobe & Mixed oligo-astrocytoma & $\mathrm{B}$ & \\
\hline 9 & 8 & $\mathrm{~F}$ & lt. fronto-parietal lobe & Anaplastic oligodendroglioma & $A^{* *}$ & \\
\hline 10 & 31 & M & rt. frontal lobe & $\begin{array}{l}\text { Mixed oligo. and anaplastic astro- } \\
\text { cytoma }\end{array}$ & A & \\
\hline 11 & 33 & M & rt. temporal lobe & Anaplastic oligodendroglioma & $\mathrm{B}$ & \\
\hline 12 & 40 & M & rt. parietal lobe & Anaplastic oligodendroglioma & $\mathrm{B}$ & \\
\hline 13 & 33 & $\mathrm{~F}$ & lt. fronto-temporal & Mixed oligo-astrocytoma & $\mathrm{B}$ & \\
\hline 14 & 30 & $\mathrm{~F}$ & rt. lateral ventricle lobe & Oligodendroglioma & $\mathrm{B}$ & \\
\hline 15 & 57 & $\mathrm{~F}$ & parietal lobe & Mixed olig-astrocytoma & $\mathrm{B}$ & \\
\hline 16 & 53 & $\mathrm{~F}$ & rt. frontal lobe & Oligodendroglioma & $\mathrm{B}$ & \\
\hline 17 & 38 & $\mathrm{~F}$ & rt. parietal lobe & Oligodendroglioma & $\mathrm{B}$ & \\
\hline
\end{tabular}

$\mathrm{B}^{*}$ : biopsy, $\mathrm{A}^{* *}$ : autopsy, $\mathrm{EM}^{* * *}$ : cases studied with electron microscope.

Table 2. Procedure for the Peroxidase Anti-Peroxidase (PAP) Method for Demonstratig GFA and S-100 Proteins in Paraffin Sections

1 Deparaffinize in xylol

2 Blocking of endogenous peroxidase : $100 \%$ methanol with $0.3 \% \mathrm{H}_{2} \mathrm{O}_{2}$ for $30 \mathrm{~min}$.

3 Normal swine serum $(1: 10)$ for $30 \mathrm{~min}$

4 Incubate with rabbit ant-GFA serum (1:1000) or rabbit anti-S-100 protein serum (1:1000) overnight, $4^{\circ} \mathrm{C}$; rinse

5 Add swine anti-rabbit $\operatorname{IgG}(1: 20)$ for 60 min.: rinse

6 PAP (1:20, DAKO) for 10 min.; rinse

7 Add fresh diaminobenzidine $/ \mathrm{H}_{2} \mathrm{O}_{2}$ solution for $3 \sim 5$ min.; rinse

8 Osmicate, Hematoxylin counterstain, dehydrate and amuont

しており，突起の一部は血管足となって血管壁に付 着している. Oligodendroglioma の基本構造を保ち ながら構成細胞に異型や多態性が現われ，核分裂像 の豊富に認められる腫瘍を anaplastic oligodendroglioma として分類した(Fig. 1D). 6 例はこ の型の組織像を示している．星形グリア系細胞の混 在の著しい 1 例と oligodendroglioma と astrocytoma の部分像を含む 5 例を mixed oligo-astrocytoma として別に分類した.この型の腫瘍に含ま
れる astrocytoma の部分の組織像のうち 1 例は多 態性を示す異型的な星形グリ只から成り anaplastic astrocytomaの組織像を示しており(Fig. 1C)，2 例 は核が偏在する細胞質肥㭌型(細胞から成っていた (Fig. 1B). 肥㭌型 astrocytoma の部分像を含むこの 2 例では oligodendroglioma の定型組織像を示す 部分との間に両型の細胞が混じり合い移行を示す所 が認められた。核周に現われた好酸性の胞体にはP. T.A.H. 染色陽性, 好酸性の強い顆粒が出現してい 
Table 3. Perikaryal Staining of GFA Protein in Pale Oligodendroglial Cells

\begin{tabular}{|c|c|c|}
\hline Histological Diagnosis & $\begin{array}{c}\text { No. of Cases } \\
\text { Studied }\end{array}$ & $\begin{array}{c}\text { No. of Cases } \\
\text { with Positive } \\
\text { Cells }\end{array}$ \\
\hline Oligodendroglioma & 6 & 2 \\
\hline Mixed oligo-astrocytoma & 5 & 2 \\
\hline Anaplastic oligodendroglioma & 6 & 2 \\
\hline Total & 17 & 6 \\
\hline
\end{tabular}

๖.

2. Oligodendroglioma の免疫組織学的所見 (Table 3.)

定型像を示す oligodendroglioma 6 例中 4 例の 腫瘍構成する boxed-in appearance を示す定型細 胞は GFA 蛋白は陰性で, S-100 蛋白は定型細胞の 一部の核と狭い胞体が陽性であった。 2 例では，定 型細胞で核周の狭い胞体が GFA 染色で陽性反応を 示し, 時に短小突起も陽性反応を示す細胞も含まれ ていた(Fig. 2B, C, D). 6 例の腫瘍共, 腫瘍組織中 に含まれる反応性星形グリア様の形態を示す細胞は GFA, S-100 蛋白陽性であった(Fig. 2A)。 6 例の anaplastic oligodendroglioma のうち 4 例は腫瘍細 胞は GFA 蛋白, S-100 蛋白共に陰性で血管周囲に 散在性に認められる少数の反応性星形グリアが陽性 所見を示していた。2例では GFA 蛋白, S-100 蛋 白陽性の反応性星形グリアが腫瘍組織中に含まれて いる (Fig. 2F) 他, 一部の perinuclear halo を示す oligo 系の細胞の核周囲の狭い胞体に GFA 染色で 陽性を示すものが認められた(Fig. 2G)。 Mixed oligo-astrocytoma では混在する星形グリア系細胞 や astrocytoma の部分像を構成する細胞は, GFA, S-100 蛋白で陽性反応を示しており (Fig. 2E), 細 胞質肥胖型の astrocytoma の部分像を示す mixed oligo-astrocytoma の 2 例では, oligodendroglioma の組織を構成する定型細胞の胞体に GFA 蛋白陽性 反応を示すものが多数観察された。一部の細胞の核 と狭い胞体は S-100 蛋白でも陽性反応を示してい る.

\section{3. 電顕的観察}

Oligodendroglioma 22 例, mixed oligo-astrocytoma の 1 例を電顕的に観察した。腫瘍は不正円 形の核を持ち, 短小突起のある細胞群から構成され ている。核は $1 \sim 2$ 個の核小体を含み核内顆粒に豊
んでいる(Fig. 3A)。クロマチン間領域に時に桿状 の封入体 ${ }^{4)}$ が認められる。この封入体は並列する細 線維構造から成っている(Fig. 3B)。細胞体は比較的 狭く電子密度も低い円形又は楕円形の系粒体の発達 が目立ち, その他小桿状の粗面小胞体，一部はりポ フスチン顆粒の構造を示す dense body 小空胞が認 められる(Fig. 3C).グリコーゲン顆粒はほとんど認 められない１例の腫陽細胞胞体に多角形又は円形 の電子密度の高い構造物が多数に観密された。この 構造物は大きさ約 $1 \sim 2.7 \mu$ で限界膜構造を欠くも のが多く, 縞状の内部構造を示している. 即ち, 約 $7 \mathrm{~nm}$ 幅の dense line が 10-15nm の間隔で規則正し く並列している(Fig. 6A)。2 例の腫瘍組織では上述 の定型細胞の他に核近傍の胞体に微細線維を豊富に 含む細胞が観察される。他に，核近傍の胞体に微細 線維を豊富に含む細胞がしばしば観察される。この 線維は $7 \sim 9 \mathrm{~nm}$ 幅で, 拡大写真では中空状の断面 像を示している(Fig. 5B)。微細線維は線維束をつく り核を取り囲んで認められる。この型の細胞胞体に は, 又 $5 \sim 10$ 対の並列する膜構造から成る annulare lamellae が観察される(Fig. 5A)。細線維を持 つ細胞で同時に多角結晶構造を含む細胞も多い. 細 線維を含む細胞には又，不規則な形の密度の高い顆 粒状構造物を認める事がある。細線維はこの構造物 と連絡している(Fig. 6B). 微小管構造は 1 例に観察 された。細胞間吵には細い細胞質突起の断面が認め られる。細胞突起は相互に入り組み，時に folding cell process として観察される事もある(Fig. 5D). 1 例の観察腫瘍は細胞間吵が広く, 微細線維を胞体と 突起に豊富に認める星形グリア系細胞が多数に観察 された。この例にはまた，細胞体を同心円状に取り 囲む細胞質突起の lamination が観察された(Fig. $5 \mathrm{C})$. 


\section{IV 考按}

1. Oligodendroglioma の組織像

Oligodendroglioma は Bailey and Cushing $(1926)^{1)}$, Bailey and Bucy (1929) $)^{5}$ によって成人の大 脳半球に好発する oligodendroglia から成る gliomaの一系として分類された。定型の組織像は細 胞性で円形の核を持つ均一な形態を示す細胞から成 り胞体は不鮮明で, 細顆粒状又は好酸性, 個々の細 胞は細胞間の線維構造によって隔てられて独特な boxed-in appearance を示している. Bailey らは Penfield 鍍銀法によって定型細胞は好銀性を示し oligoglia の形態を模倣する事を確認する一方, 腫瘍 組織内に星形グリアや海綿芽細胞の混在のある事を 指摘した。この腫瘍を鍍銀法で観察した Hortega ${ }^{6)}$ は定型細胞の他に, 種々の程度に星形グリアゃ astroblast が認められると記載している. Oliogodendroglioma の 1 例を辻山法によって観察した 所，好銀性を示す定型細胞は Hortega の oligodendroglia の形態を模倣しているが, Cajal 法を行 なうと好銀性の強い太い突起を持った海綿芽又は星 膠芽細胞様の細胞もかなり含まれていた。検索17例 中 pure type は 6 例のみで， 6 例は oligodendroglioma の組織部分の他に astrocytoma の組織部分 の混在する，或いは星形グリア系細胞と定型細胞と が密に入り混じる mixed oligo-astrocytoma の所 見を示していた。

2. Oligodendroglioma と GFA 蛋白, S-100 蛋 白

GFA 蛋白は Eng ら) によって gliosis を示す七 卜脳組織から抽出された蛋白で, 星形グリアの骨格 線維である glial filament の構成蛋白と考えられて いる.免疫組織学的に脳組織では，この蛋白は主と して星形グリアの胞体, 特にその突起に認められる. Eng ら， 8) Velasco ら ${ }^{9)}$ は酵素抗体法によって oligodendroglioma の腫瘍組織内の GFA 蛋白の局 在を検索し, 定型細胞は陰性, 混在する星形グリア 系細胞は陽性と記載している。17例の oligodendroglioma を免疫組織化学的に観察した所, 反応性腫瘍 性星形グリアの他に， 6 例に boxed-in appearance の明瞭な細胞の核周囲の胞体に GFA 蛋白陽性の細 胞が認められた。Van der Meulen ${ }^{10)}$ は Grade III oligodendroglioma 13例中 3 例の定型細胞胞体に GFA 蛋白の陽性反応を認めており，Kepes ら ${ }^{11)}$ は
検索19例中15例の定型細胞に GFA 陽性細胞を認め ている. GFA 蛋白陽性の oligo 系細胞の存在は星 形グリア系細胞との移行又は星形グリア系細胞への 異分化を示唆している。

S-100 蛋白は Moore (1965) ${ }^{12)}$ によってウシ脳よ り抽出精製された蛋白で, 脳では主として glia, 特 に星形グリアに認められる。oligodendrogliaについ ての記載は一致していないが,その一部は S-100 蛋 白陽性との報告もある ${ }^{13)}$. Haglid ら ${ }^{14)}$ は螢光抗体 間接法で脳腫瘍を検索し oligodendroglioma の一 部に陽性反応を認めている。酵素抗体法で S-100 蛋 白の局在を検討した熊西 ${ }^{15)}$ 以この蛋白が主として 腫瘍細胞の核に存在する事を指摘している。著者の 検索では定型的な oligo 系細胞の一部の核と狭い胞 体は陽性反応を示していた。GFA 蛋白染色に見られ る線維束状の Perikaryal staining は認められない. S-100 蛋白は特定の細胞質内構造の構成蛋白ではな く，核と胞体に広く局在する為と考えられる。

3. Oligodendroglioma の超微像

Oligodendroglioma は核と細胞質の電子密度の 高い細胞でゴルジ装置, 粗面小胞体が良く発達し細 胞質の突起に $25 \mathrm{~nm}$ 幅の微小管構造を豊富に含む細 胞と考えられている ${ }^{16)}$. Mori and Leblond ${ }^{17)}$ は細 胞の大きさと胞体の密度によって oligodendroglia を 3 型に分類している. glial filaments は認められ ない. oligodendroglia の腫瘍, oligodendroglioma の超微像についての記載は必うずしも一致していな い. Luse $(1960)^{2)}$ は, 胞体汸広く小器官に乏しい pale cell を定型細胞として紹介したが，Garcia (1970) ら ${ }^{18)}$ は小器官に豊み電子密度の高い狭い胞 体を持つ細胞を定型腫場細胞として記載されてい る. Raimondi $(1962)^{19)}$, 谷 $(1966)^{20)}$ は 6-8nm 径の filaments が胞体内に存在すう事を指摘したが, 澤 田ら $(1971)^{21)}$, Garcia (197门) $)^{18)}$ は $20 \mathrm{~nm}$ 径の microtubules が定型細胞に豊富に存在すると記載 されている。腫瘍細胞胞体内门特殊な構造物として 記載されているものに, 多角結晶構造2223) がある. 著者の検索例の 2 例には filarnents をもつ細胞が多 数出現していた。 Filaments は直径 7-9nm で intermediate filament に属し中空状の断面像を示して いる. Filaments は核を取り国んで線維束を形成し ている. Filaments は細胞質突起には無く，また同 時に多角結晶構造を含む細胞忍あるので反応性又は 腫瘍性星形グリアではなく, oligo 系の腫瘍細胞と 
考えられる. GFA 染色で perikaryal staining を示 す pale cell はこの超微像を示す細胞に対応するも のと考えられる。細線維束に認められる不規則な形 の顆粒状の密度の高い構造物は Rosenthal 線維の 超微像 ${ }^{24)}$ に一致している. Van der Meulen ${ }^{10)}$, Kepes ${ }^{11)}$ は酵素抗体法, 電顕観察で著者と同様の所 見を認めている。腫瘍性に増殖した oligodendroglia の一部は星形グリア系細胞への移行像を示すものと 考えられる.Van der Meulen ${ }^{10)}$ は酵素抗体法に よって定型細胞の一部に GFA 蛋白陽性細胞を認 め, 腫瘍がある程度組織学的悪性度を示す場合に星 形グリアへの移行を示す細胞が出現すると考えてい る. Filaments を持つ腫瘍細胞に annulate lamellae が認められた事はこの点で興味深い。この膜様構造 は増殖力の強い細胞に観察される事が知られている からである。一例の検索例に細胞体を取り囲こむ細 胞質突起の concentric lamination が観察された。 この構造は Robertson (1962) ${ }^{25}$, Cervós-Navarro $ら^{26)}$ が oligodendroglioma で記載した構造である. 腫瘍構成細胞の潜在的な形態分化の表現と考えられ るが，この構造は反応性に増殖した星形グリアにも 記載されており，腫瘍性の oligodendroglia にのみ 特徵的な構造とは考えにくい.

\section{VI ま と め}

1. Oligodendroglioma の生検, 剖検例17例の腫 瘍組織を組織学的に検索した。17例のうち，6 例は 定型組織像を示す pure type のoligodendroglioma で， 6 例は mixed oligo-astrocytoma，他の 5 例は 悪性の組織学的特徵の加わった anaplastic oligodendroglioma であった。定型組織像を示す oligo- dendroglioma の組織像を辻山鍍銀法で検索した。 定型細胞は好銀性を示し, oligodendroglia の形態を 模倣している.Cajal 鍍銀法では好銀性を示し血管 足のある星形グリア系細胞の混在が認められた。

2. Oligodendrogliomaに含まれる, 或いは混合構 成を示す星形グリア系細胞は免疫組織化学的に S100 蛋白, GFA 蛋白陽性であった。検索 10 例中 6 例 では boxed-in appearance を示す細胞で核近傍の 狭い胞体が GFA 蛋白陽性の所見を示すものが多数 に観察された。

3. Oligodendrogliomaの構成細胞は電顕的に, 小 器官の良く発生した細胞で, 細胞質突起は細く短か い. 1 例の腫瘍細胞体に多角結晶構造を多数に認め た. 2 例の腫瘍組織には, 核近傍胞体に 7-9nm 幅の glial filaments を豊富に含む細胞が観察された。こ の細胞は GFA 蛋白染色で perikaryal staining を 示す細胞に対応するものと考えた。この細胞には annulate lamellae, 時に Rosenthal 線維構造が観 察され, 1 例の検索例の構成細胞に細胞質突起の concentric lamination が観察された.

4. ヒトの oligodendroglioma は組織学的に, 種々 の程度に星形グリア系細胞の混在が認められる.免 疫組織学的, 電顕的に定型腫瘍細胞にも星形グリア との移行像を示す細胞が認められた。

\section{謝辞}

終始御指導と御校閲を賜つた恩師石田陽一教授に深甚 なる謝意を捧げます。また御援助をいただいた中里洋一 講師, 平戸純子医学士をはじめ群馬大学第一病理学教室 の各位に感謝致します。 


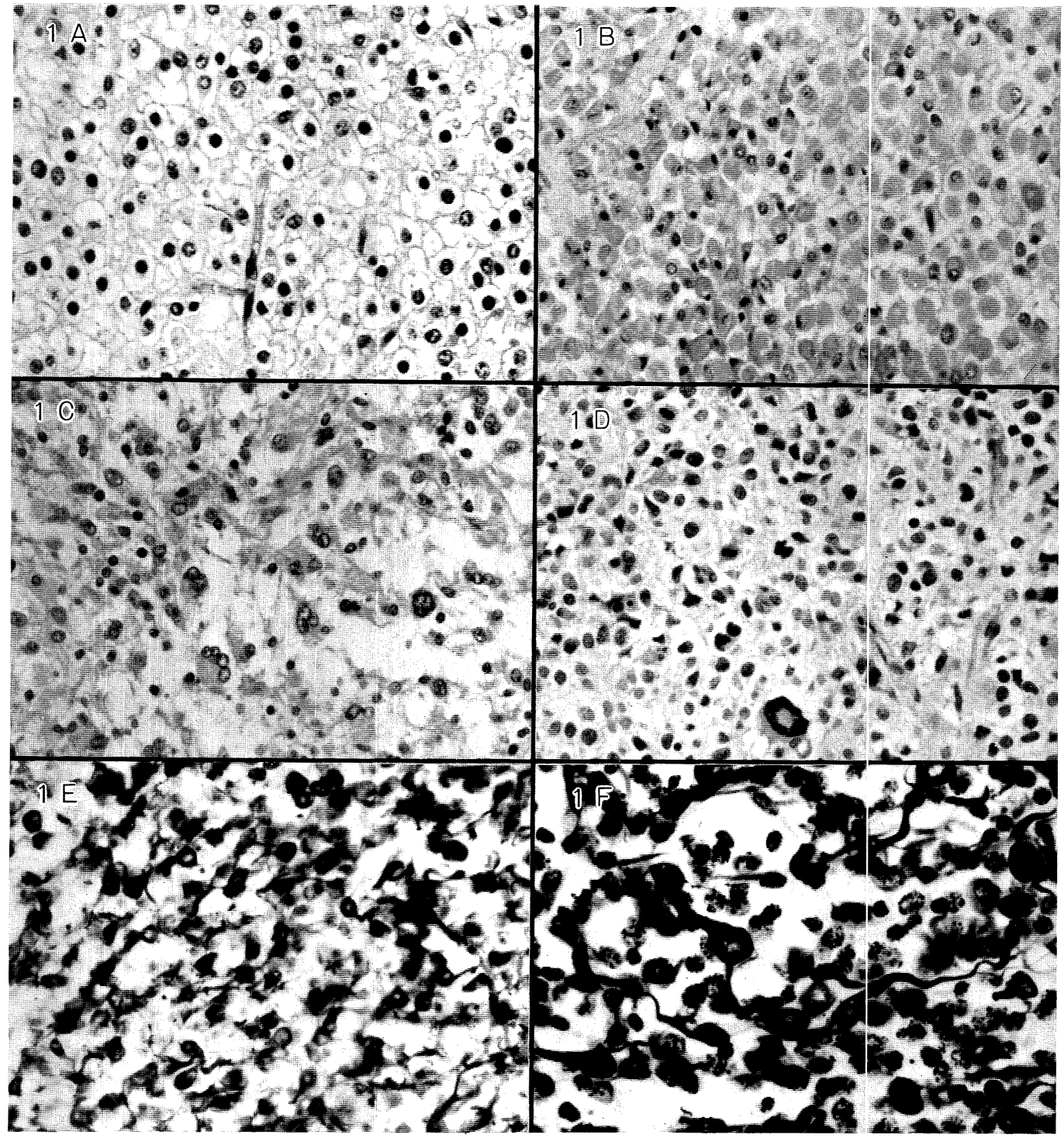

Fig 1. A : Histology of an oligodendroglioma with typical boxed-in appearance. H.E. stain. $\times 480$

B : Mixed glioma. Area of astrocytoma made up of plump cells. H.E. stain

C : Mixed glioma. Area of astrocytoma composed of pleomorphic cells. H.E. stain. $\times 500$

D : Anaplastic oligodendroglioma. H.E. stain. $\times 560$

E : Tsujiyama's technique for oligodendrocyte, showing positively impregnated neoplastic cells. $\times 440$

F : Cajal's silver method for macroglia, showing argylophilic uni- and bi-polar cells. $\times 760$ 


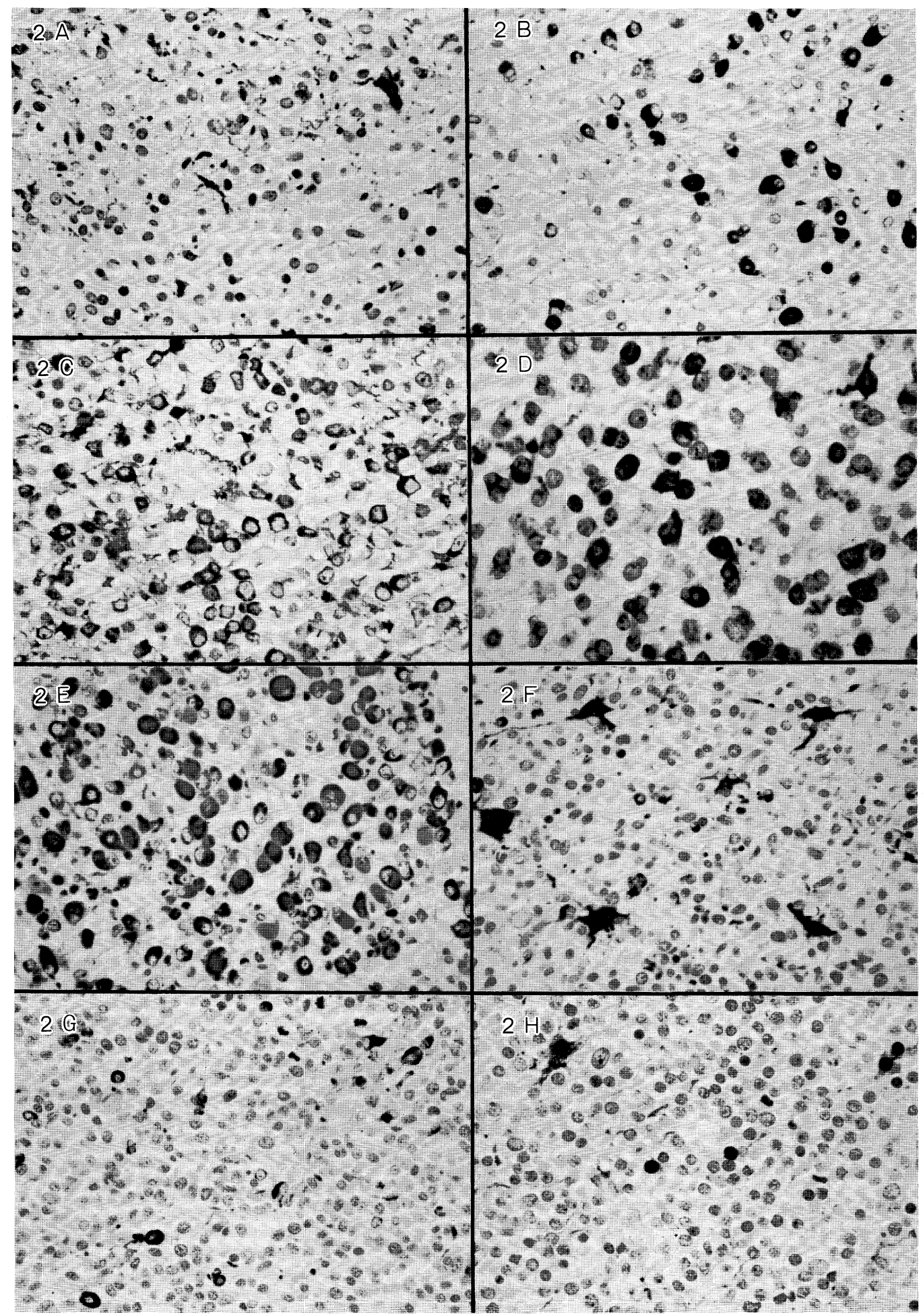


Fig 2. A : Immunoperoxidase stain for GFA. Immunoreactive materials are found confined to astrocytic cells and fibers. Neoplastic oligodendrocytes are generally unstained. $\times 550$

B : Perikaryal staining of pale oligodendroglial cells for GFA. $\times 460$

C : A large number of pale oligodendroglial cells with staining for GFA. $\times 480$

D : Oligodendroglial cells with staining of perinuclear narrow cytoplasm. GFAPAP. $\times 1,100$

E : Mixed glioma. Intensely stained plump astrocytic cells. GFA-PAF. $\times 450$

F : Anaplastic oligodendroglioma. GFA-positive reactive astrocytes engulfed within the tumors. $\times 450$

G : Anaplastic oligodendroglioma. Fewer cells with perikaryal GFA material. $\times 450$

$\mathrm{H}:$ Immunoperoxidase stain for S-100 protein. Immunoreactive materials are seen in some oligodendroglial cells. $\times 450$ 


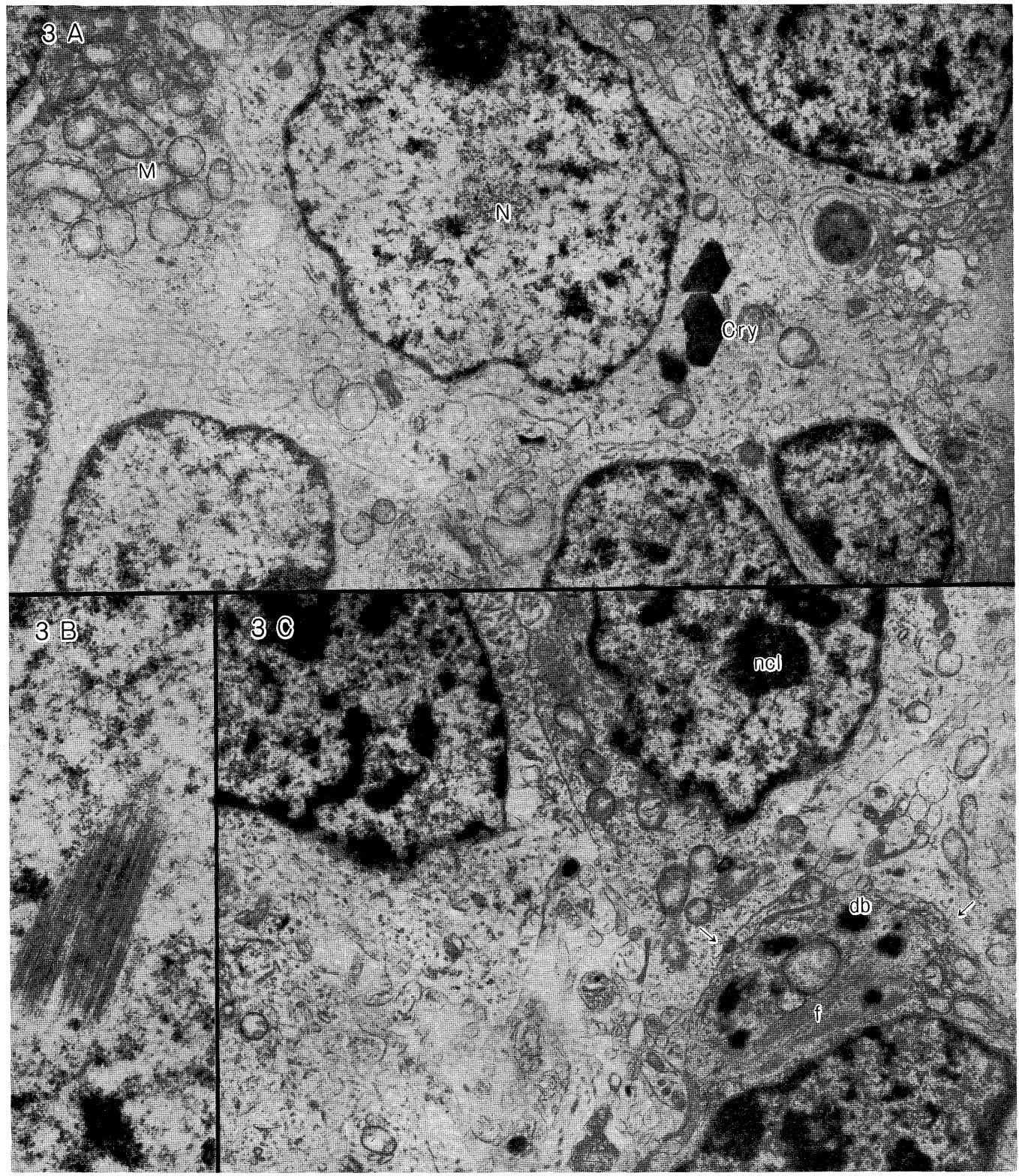

Fig 3. A : Low power electron micrograph of an oligodendroglioma. The cytoplasm of neoplastic cells varies in amount with short, delicate cytoplasmic processes. Crystalline structures (Cry) are found in one of the cells. $\times 7,700$

B : Intranuclear rodlets. $\times 21,000$

C : Low power view of another oligodendroglioma. Arrows indicate a cell with bundles of filaments (f) and osmiophilic bodies of irregular shape (db). $\times 8,000$ 


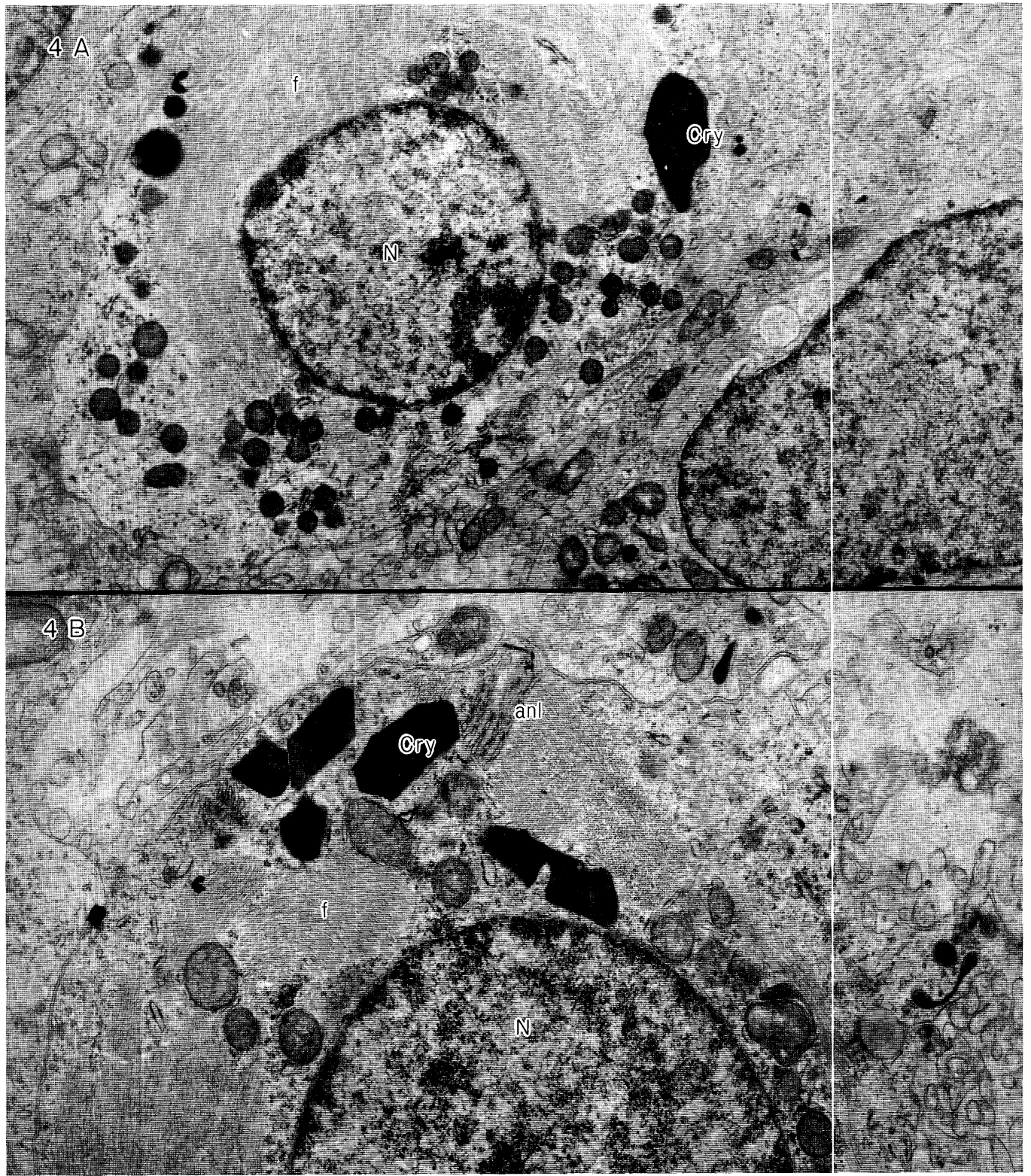

Fig 4. A, B : Electron micrographs, showing neoplastic oligodendroglicl cells with bundles of filaments (f) and polygonal crystalline bodies. $\times 7,400, \times 15,000$ 


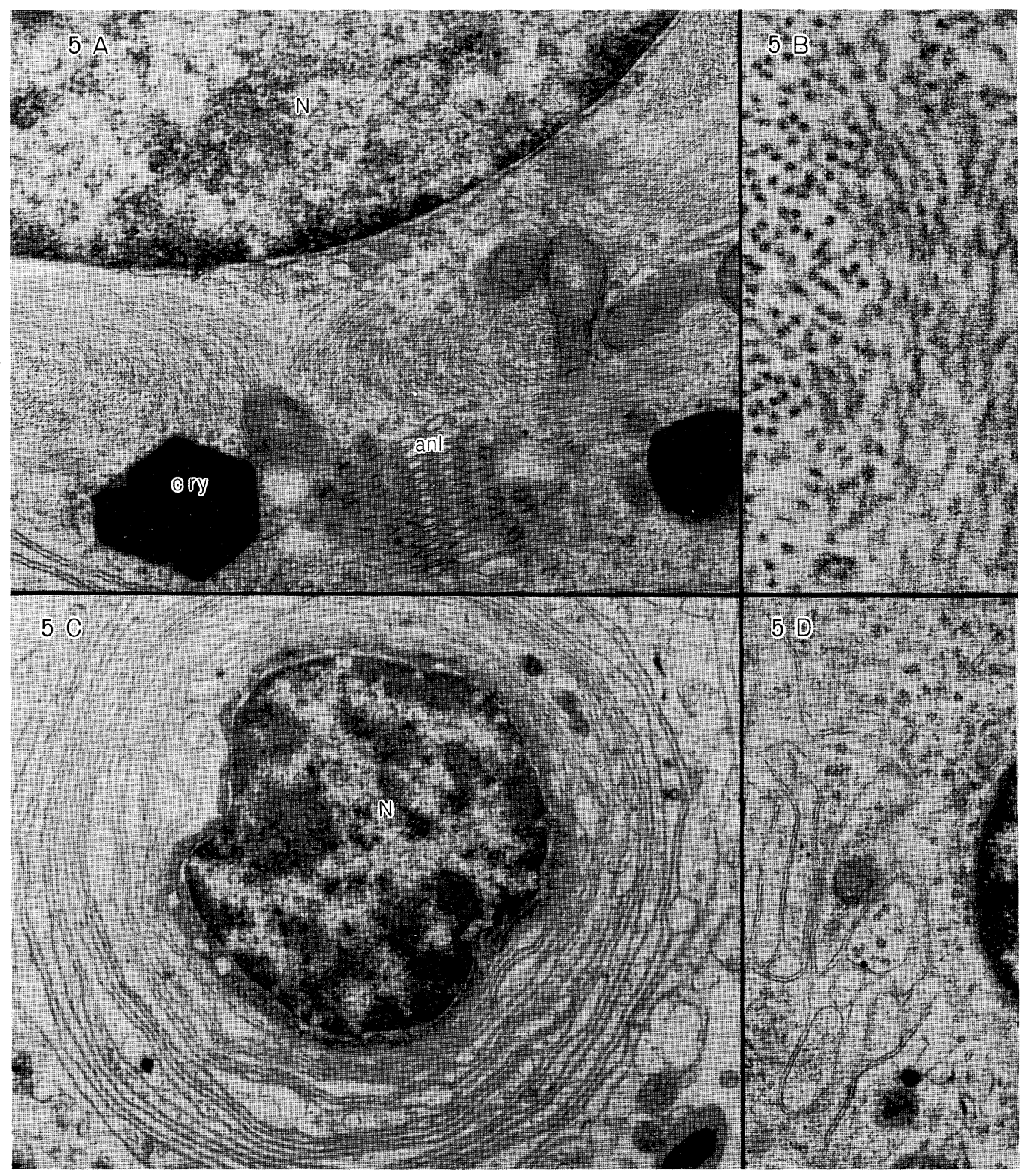

Fig 5. High power view of perikaryal cytoplasm of a neoplastic oligodendroglial cell, showing filament bundles, crystalline bodies and annulate lamellae (anl). $\times 23$, 000

B : Glial filaments, longitudinally and crossly sectioned. $\times 99,000$

C : Concentric lamination of cytoplasmic process around a cell body. $\times 9,800$

D : Folding of the cytoplasmic processes. $\times 12,000$ 


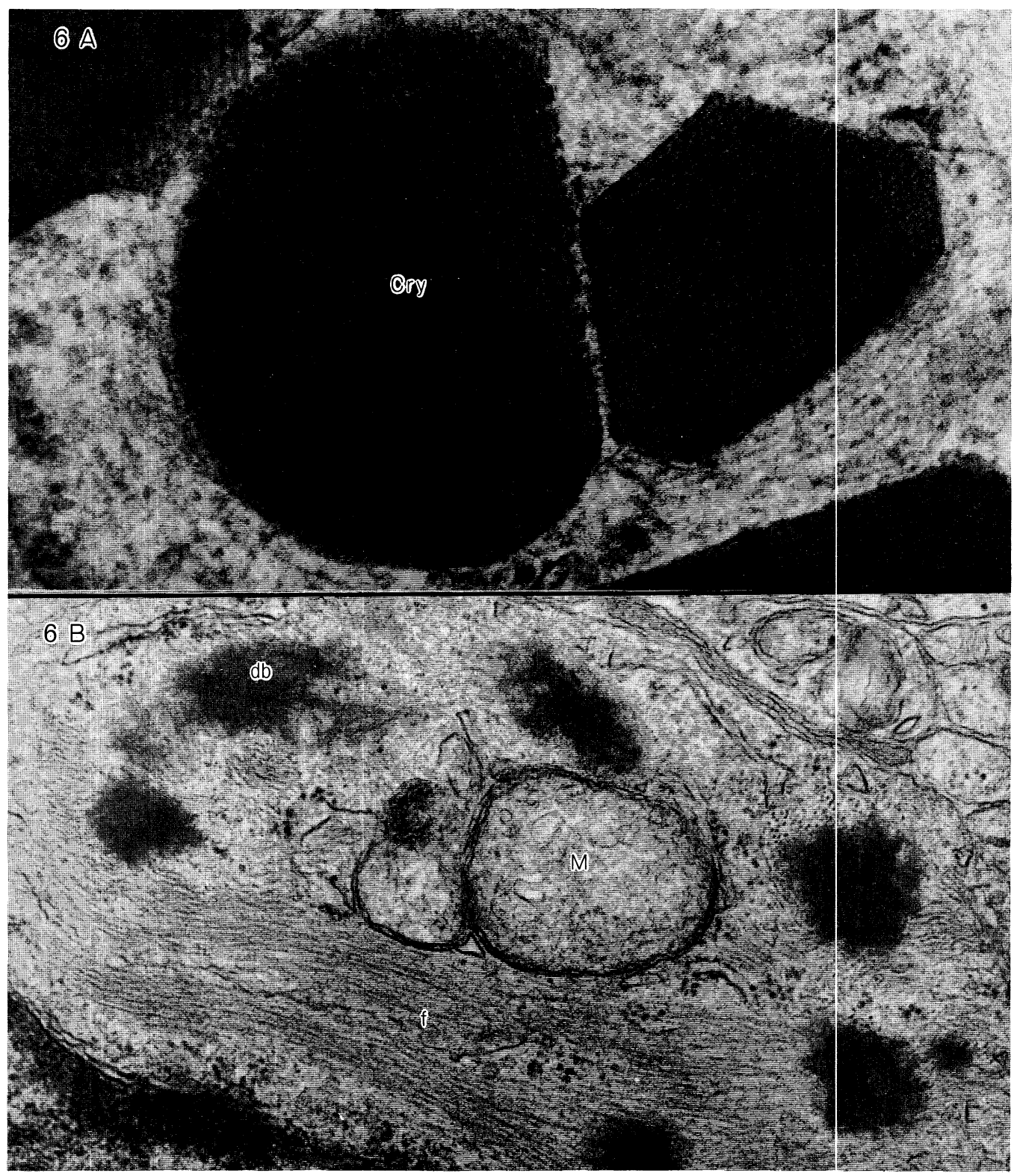

Fig 6. A : High resolution electron micrograph, showing polygonal crystalline bodies. They consist of parallel layering of $7 \mathrm{~nm}$ dense lines with about $110 \mathrm{~nm}$ regular intervals. One of them show honey-combed pattern. $\times 80,000$

B : Irrcgular amorphous densc bodics (db) which arc surrounded by and associatcd with glial filaments. The bodies appear to correspond to the Rosenthal fibers. $\times$ 36,000 


\section{文}

1) Bailey,P. and Cushing,H. : A classification of the tumors of the glioma group on a histogenetic basis with a correlative study of prognosis. Lippincott. philadelphia., 1926.

2) Luse,S.A. : Electron microscopic studies of brain tumors. Neurology. $10: 881-905,1960$.

3）山口晴保： 神経特異 S-100 蛋白, GFA 蛋白 のラット神経組織, ヒト脳腫瘍組織内局在に関 する免疫組織学的研究. 脳神経 $32: 1055-1064$, 1980.

4) Vazquez,J.J. and Cervós-Navarro,J. : Intranucleore stabformige Gebilde bei einem Oligodendrogliom. Acta Neuropath. (Berl.) $13: 289-293,1969$.

5) Bailey,P. and Bucy,P.C. : Oligodendrogliomas of the brain. J. Pathol. Bact., $32: 735$ 751,1929 .

6) Rio-Hortega,P. del : The microscopic anatomy of tumors of the central and peripheral nervous system. Charles C Thomas Publisher, Springfield, 1962. pp.47-54.

7) Eng, L.F., Vanderhaeghen,J.J., Bignami,A. and Gerstl,B.: An acidic protein isolated from fibrous astrocytes. Brain Res., $28: 351$ 354,1971.

8) Eng,L.F. and Rubinstein,L.J. : Contribution of immunohistochemistry to diagnostic problem of human cerebral tumors. J.Histochem. Cytochem., 26 : 513-523, 1978.

9) Velasco, M.E., Dahl,D., Roessmann,U. and Gambetti,P. : Immunohistochemical localization of glial fibrillary acidic protein in human glial neoplasms. Cancer $45:$ 484-494, 1980.

10) Van der Meulen,J,D.M., Houthoff,H.J. and Ebels,E.J. : Glial fibrillary acidic protein in human gliomas. Neuropath. appl. Neurobiol. 4:177-190, 1978.

11) Kepes,J.J. and Meneses,C.O.A. : Astrocytic differentiation of neoplastic oligodendrocytes. in abstracts of $1 \mathrm{X}$ th. International Congress of Neuropathology, Vienna, 1982,p.
158.

12) Moore,B.W.: A soluble protein characteristic of the nervous system. Biochen.Biophys. Res.Commun., $19: 739-744,1965$.

13) Coccia,D: lmmunocytochemical localization of S-100 protein in the brain of adult rat. Cell tissue Res. 214 : 529-540, 1981.

14) Haglid,K., Carlsson,C.A. and Stavrou,D. : An immunological study of human brain tumors concerning brain specific proteins S100 and 14.3.2.. Acta Neuropath.(Berl.), 24 : 187-196, 1973.

15）熊西敏郎： 脳特異蛋白 S-100 と脳腫瘍一酵素 抗体法による検索一神経進歩, $24: 264-270$, 1980.

16) Peters,A.,Palay,A. and Webster,H. de F. : The fine structure of the nervous system. W. B.Saunders Philadelphia, 1976, pp250-254.

17) Mori,S.and Leblod,C.P. : Electron microscopic identification of three classes of oligodendrocytes and a preliminary study of their proliferative activity in the corpus callosum of young rats.J.Comp.Neurol., $139: 1-30,1970$.

18) Garcia,J.H. and Lemmi,H. : Ultrastructure of oligodendroglioma of the spinal cord. Amer.J.Clin. Pathol., 54 : 757-765, 1970.

19) Raimondi, A. J. Mullan, S. and Evans, J.P. : Human brain tumor. An electron microscopic study. J. Neurosurg. $19: 731-751,1962$.

20）谷 栄一：摘出脳腫瘍細胞内に観察された多 角結晶様構造. 神経進歩, $10: 327-330,1966$.

21）澤田稔夫, 北村勝俊：乏突起膠腫. 電子顕微 鏡による細胞組織図譜。山田英智, 内溒耕二, 渡辺陽之助編, 医学書院, 東京, 1971, 第VI巻, pp254-259.

22) Tani, E., Yamashita, J., Takeuchi, and Handa, H.: Polygonal crystalline structures and crystalline aggregates of cylindrical particles in human glioma. Acta Neuropath. (Berl.), $13: 324-337,1969$.

23) Holmes,R.: Zur Formale Genese Kristalliner Structuren in Oligodendrogliomen. Acta Neuropath. (Berl.), 13 : 289-293, 1969. 
24) Herndon, R. M., Rubinstein, L, J., Freeman, J. M. and Matherson.G: Light and electron microscopic observations on Rosenthal fibers in Alexander's disease and multiple sclerosis. J. Neuropath. Exp. Neurol. 29 : 525-551,1970.
25) Robertson, D. M. and Vogel, F. S. : Concentric lamination of glial processes in oligodendrogliomas. J.Cell Biol.,15 : 313-334, 1962.

26) Cervós-Navarro and Pehlivan,N. Acta Neuropath.(Berl.) Suppl VII : 91-93,1981.

\section{IMMUNOHISTOCHEMICAL AND ELECTRON MICROSCOPIC STUDIES OF OLIGODENDROGLIOMAS}

\section{TSUGIYASU KANDA}

First Department of Pathology, School of Medicine, Gunma University, Maebashi (Director: Prof. Yoichi Ishida)

Seventeen cases of oligodendrogliomas were investigated immunohistochemically for glial fibrillary acidic protein (GFAP) and S-100 protein. Three of them were studied with the electron microscope. Six of seventeen cases show a well defined histological appearance of classic oligodendroglioma. Six cases contain area of gemistocytic or pleomorphic astrocytoma and are classified as mixed oligo-astrocytoma. Five other cases show the histology of anaplastic oligodendroglioma. The entrapped reactive astrocytes and the cells comprising areas of astrocytoma in mixed glioma stain positively with PAP immunoperoxidase method for GFAP and S-100 protein. In 2 cases of classic oligodendrogliomas and 2 cases of mixed oligo-astrocytomas, varying numbers of pale oligodendroglial cells show perikaryal staining for GFAP. This perikaryal inmmunoreactivity is found to retain in cells of 2 cases of anaplastic oligodendrogliomas. In electron microscopy the cytoplasm of neoplastic oligodendroglial cells appear variable in amount with short delicate cyoplasmic processes. Polygonal crystalline structures are found in one case. Occasional cell nuclei contain rodlets. The cytological feature which appear to correspond to immunoreactivity is the presence of bundles of $7-9 \mathrm{~nm}$ glial filaments encircling about the nucleus. The filament containing cells also contain annulate lamellae, crystalline bodies and occasionally irregular amorphous dense materials correspoding to the structure described as Rosenthal fiber. Highly laminar systems are found only in one of three cases. These findings suggest that neoplastic oligodendrocytes may share the common features with astrocytic elements and that they are capable of differentiating along astrocytic lines.

Key words: oligodendroglioma, GFAP,S-100, crystalline bodies, glial filaments 